\title{
High-grade serous ovarian cancer: the clone wars
}

\author{
Aleksander Salomon-Perzyński ${ }^{1}$ Magdalena Salomon-Perzyńska ${ }^{2} \cdot$ \\ Bogdan Michalski ${ }^{2}$ Violetta Skrzypulec-Plinta ${ }^{3}$
}

Received: 8 November 2016 / Accepted: 4 January 2017 / Published online: 3 February 2017

(C) The Author(s) 2017. This article is published with open access at Springerlink.com

\begin{abstract}
Background The last 5 years' studies using next-generation sequencing provided evidences that many types of solid tumors present spatial and temporal genetic heterogeneity and are composed of multiple populations of genetically distinct subclones that evolve over time following a pattern of branched evolution. The evolutionary nature of cancer has been proposed as the major contributor to drug resistance and treatment failure. In this review, we present the current state of knowledge about the clonal evolution of high-grade serous ovarian cancer and discuss the challenge that clonal evolution poses for efforts to achieve an optimal cancer control.

Methods A systemic search of peer-reviewed articles published between August 2007 and October 2016 was performed using PUBMED and Google Scholar database.

Results and conclusions Recent studies using next-generation sequencing have allowed us to look inside the evolutionary nature of high-grade serous ovarian cancer, which in the light of current evidence can explain the relapsing course of the disease frequently observed in the clinical practice. Since only minimal improvement in the survival of patients treated with standard therapy has been observed in the last decade, novel molecular targeted therapies are
\end{abstract}

Magdalena Salomon-Perzyńska salomon.perzynska@gmail.com

1 Department of Internal Medicine and Oncological Chemotherapy, School of Medicine in Katowice, Medical University of Silesia, Katowice, Poland

2 Department of Gynaecology Oncological, School of Health Sciences in Katowice, Medical University of Silesia, Katowice, Poland

3 School of Health Sciences in Katowice, Medical University of Silesia, Katowice, Poland of great interest in high-grade serous ovarian cancer. However, both spatial and temporal intratumoral genetic heterogeneity is a major challenge for personalized medicine, and greater knowledge of the molecular rules that drive tumor evolution through space and time is required to achieve a long-term clinical benefit from personalized therapy.

Keywords Ovarian cancer · Clonal evolution - Drug resistance $\cdot$ Genetic heterogeneity $\cdot$ Genomic instability

\section{Introduction}

High-grade serous ovarian cancer (HGSOC), the most common and aggressive form of the epithelial ovarian cancer (EOC), remains the leading cause of cancer-related death among all gynecological cancers in the developed parts of the world [1,2].

The majority of cases show a significant, but transient response to standard therapy including debulking surgery followed by platinum-based chemotherapy, and the development of resistance is almost permanently inscribed in the clinical course of the disease [3]. Therefore, the emergence of drug-resistant disease is a major problem in the clinical management of HGSOC, and in the context of the still unsatisfactory treatment outcomes, deciphering the molecular mechanisms that contribute to drug resistance is the greatest challenge in the area of HGSOC molecular research.

The last 5 years' studies using next-generation sequencing provided evidences that many types of solid tumors present spatial and temporal genetic heterogeneity and are composed of multiple populations of genetically distinct subclones that evolve over time following a pattern of branched evolution in a similar manner to the Darwinian 
evolution of species [4-9]. This evolutionary nature of cancer has been proposed as the major contributor to drug resistance and treatment failure [10].

In this review, we present the current state of knowledge about the clonal evolution (CE) of HGSOC and discuss the challenge that $\mathrm{CE}$ poses for efforts to achieve an optimal cancer control.

\section{Genomic instability in HGSOC}

Large-scale genomic analyses demonstrated that HGSOC exhibits a high degree of genomic instability (GI) arising as a result of DNA repair defects caused mainly by TP53 mutations and homologous recombination (HR) deficiency, occurring in $96 \%$ and almost $50 \%$ of cases, respectively $[11,12]$. During tumorigenesis GI promotes the acquisition of further DNA alterations leading to genetic diversity between cancer cells and creating the possibility of coexistence of genetically distinct subclones within the same tumor [13]. Therefore, GI is a source of intratumoral genetic heterogeneity (ITH) and one of the most important driving forces of CE. Subclones can benefit from GI by acquiring new genomic events that confer a selective advantage during ongoing evolution, thus a high level of GI is generally associated with emerging of treatment resistance and poor prognosis in various cancer types [14-16]. However, a high degree of GI can also have an unfavorable effect on the fitness of cancer subclones by enabling the acquisition of deleterious genomic alterations that provide a selective disadvantage [17] and, consequently, limit tumor growth, and/or increase tumor response to the cytotoxic therapy. This is particularly true for HGSOC, where the studies have shown that a greater level of GI is associated with improved outcomes, mainly due to a higher response rate to platinum-based chemotherapy $[18,19]$. It is consistent with clinical observations that HR-deficient cases with a highly unstable genome exhibit enhanced platinum sensitivity and improved overall survival (OS) compared to HR-intact cases [20]. Since HR deficiency is associated with better response to platinum agents, the restoration of BRCA1 and BRCA2 function is thought to play an important role in emerging of platinum resistance [21]. Recently, the large-scale genomic analysis of chemoresistant HGSOC, showed HR deficiency only in 2 out of 12 platinum-refractory cases (both as a consequence of the somatic methylation of BRCA1 which cannot be considered as an equivalent to germline mutation) while reversions of germline BRCA1/2 mutations have been found in 5 out of 10 relapse cases. Moreover, one autopsy case was found to have several independent subclonal BRCA2 reversion events detected in the different tumor metastatic sites at the time of relapse [12]. Therefore, it appears that in some HGSOC cases an optimal level of GI may be required to provide cancer subclones with the ability to survive and to expand under selective pressure of chemotherapy. Further instability, may in turn be unfavorable for subclones leading to their increased chemosensitivity. This hypothesis is supported by a recent report demonstrating an increase in genomic stability within the residual subclones after the course of neoadjuvant chemotherapy [22]. Further studies should evaluate how various levels of GI, which are seen in HGSOC, affect the ITH, the tumor evolutionary potential and, ultimately, the tumor response to the treatment.

\section{Clonal evolution of pre-treatment disease}

To investigate clonal heterogeneity in HGSOC, Bashashati et al. obtained 29 spatially separated samples from 5 patients with newly diagnosed stage III-IV HGSOC [7]. Exome sequencing, copy number analysis, target amplicon deep sequencing and gene expression profiling confirmed the presence of extensive intratumoral genomic and transcriptomic heterogeneity with TP53 mutation as the clonally dominant key driver event acquired early in the tumorigenesis. Importantly, alterations in key driver genes such as PIK3CA, CTNNB1, PDGFR, NF1, SH3GL1, RBM15 were found to be subclonal, indicating that they have been acquired during tumor evolution and confirming that key driver events contributing to cancer initiation, progression and maintaince are not always clonally dominant (present in all cancer cells), but also can be present subclonally (present only in a subset of cancer cells) [4, 5, 23]. These subclonal mutations along with non-genetic factors can lead to a phenotypic diversity between cancer cells and provide the fitness advantage to subclones, reducing clinical benefit of cancer therapy [23, 24]. Indeed, some of the subclonal mutations found by Bashashati et al. were associated with alteration in gene expression profile supporting their role in shaping subclonal phenotypes and intratumoral phenotypic heterogeneity.

The results reported by Hoogstrat et al. [25] highlighted that the patterns of CE vary across HGSOC cases. These findings also suggest that CE may occur independently at the level of mutational processes as well as genomic rearrangements, and alterations in genomic rearragements may, independently from mutations, affect the intratumoral phenotypic diversity. They took 15 spatially separated samples from different tumor sites from 2 treatment-naive patients with stage IIIC-IV HGSOC. The first case showed extensive genomic and transcriptomic intratumoral heterogeneity with most marked differences in the genomic rearrangement, the gene expression profile and key cancer pathways activation between the samples from the primary tumor site in the ovary and those obtained from peritoneal and 
omental metastases. However, the second case was found to be much more homogenous with respect to genomic rearrangement, mutational profile and gene expression pattern. Importantly, in the first case there were no mutations unique to metastatic samples and all mutations identified in these samples were also found in samples from the right ovary. In the second case only two mutations were unique to the tumor metastatic site, whereas all other detected mutations were shared between all samples. This supports the results from the Lee et al. [26] case report and suggests that in some cases of pre-treatment HGSOC, intraperitoneal metastases may arise with only a little accumulation of new somatic mutations.

Studies showed a rather consistent picture of HGSOC as a dynamic entity composed of multiple populations of genetically and phenotypically distinct subclones evolving from a single ancestral clone following patient-specific patterns of branched evolution [7, 25-27]. In the context of complex tumor structure it is most likely that the CE of untreated HGSOC is mainly driven by selective pressures imposed by highly heterogeneous (both spatially and temporally) tumor microenvironment (TME) [28, 29]. During ongoing evolution, subclones are selected according to their fitness to survive in divergent microenvironmental conditions [29, 30]. Selection is based on the phenotypes and subclones that have phenotypic advantage in given environmental landscape undergo further clonal expansion [31]. Phenotypes are not, however, the permanent features of cancer cells and do not result solely from cell-autonomously acting factors $[10,32,33]$. Beyond genetic, epigenetic, transcriptomic and proteomic factors, also variations in local microenvironmental niches may affect phenotypes of cancer cells and consequently influence their fitness [10, 24, 29, 34]. These interactions are not, however, directed unilaterally and cancer cells can likewise modulate their microenvironments enforcing, e.g., dynamic changes in their own phenotypes [24, 35]. Therefore, the TME should be considered not simply as a "passive" source of various selection forces that promote certain phenotypes, but rather as a dynamic, complex structure actively affecting the pathways of cancer cell evolution.

It appears that in an advanced-stage HGSOC the presence of extensive phenotypic diversity as well as noticable differences in chemosensivity between cancer cells isolated from different tumor deposits [36] can be in part explained by divergent selective pressures acting on tumor cell subpopulations in various metastatic niches. As clinical observations indicate that in advanced-stage EOC the initial disease distribution is prognostically relevant regardless of achieving a cytoreduction to microscopic residual disease (RD) [37], the role of microenvironmental conditions in given metastatic regions in selection or "storage" of resistant subclones leading to tumor maintaince and progression should be evaluated in further studies. There is also a need to assess whether the metastatic niches in the given metastatic organ are able to promote repeatable genotypes and phenotypes across different HGSOC cases.

The coexistence of genetically dissimilar subclones widespread within the three-dimensional (3D) tumor space can lead to interclonal interactions which are not limited, however, to a simple competition for space and resources during ongoing selection [32, 38-40]. As a recent study using mouse xenograft model of breast cancer suggests, the heterogeneous cancer cell population may include minor subclones too indolent to win a competition and grow out/ expand, but able to promote proliferation of other subclones [32]. Along with the results of the study in glioblastoma [38], it supports the potentially relevant role of minor subclonal populations in driving cancer growth and maintaining tumor heterogeneity. Moreover, a study based on transgenic mouse model of multiple myeloma suggests that the inability of minor subclones to compete efficiently does not necessarily lead to their exclusion from the cancer cell population by more agressive subclones. Dominant subclones may indeed supress minor subclones, but they also may coexist with them or even promote their proliferation [40]. These findings shed new light on the role of interclonal interactions in cancer evolution and provide additional evidence to perceive tumor as a complex topological "ecosystem" rather than a simple mass of transformed epithelial cells. Recently, several studies revealed that 3D models of EOC cell lines that reconstitute complex tumor architecture better reflect cancer cells behavior and their potential for emergence of resistance than two-dimensional models [41-43] supporting the impact both cell-cell and cell-stroma interactions on EOC biology. Due to the subclonal complexity of HGSOC, further studies should evaluate whether interclonal interactions have a relevant effect on tumor evolution prior to the treatment, on tumor response to the treatment, as well as on the development of platinum-resistant and, especially, platinum-sensitive recurrence [44].

\section{HGSOC evolution during the course of treatment}

The emergence of treatment resistance followed by initial response to standard therapy resulting in tumor relapse remains a main clinical problem in the management of most HGSOC cases reducing the possibility to cure the advanced-stage disease $[3,45]$.

For heterogeneous tumor cell population, cancer therapy constitutes a selection pressure widely affecting the patterns of tumor evolution [10]. Beyond mechanical and/ or cytotoxic eradication of sensitive subclones, treatmentrelated selection forces can also favor the expansion of 
subclones genetically and/or phenotypically best adapted to therapy-induced conditions leading to dynamic changes in the subclonal composition of cancer [46-48]. It should be noted, however, that because of the existence of a structural complexity of the tumor, the adaptive changes in the tumor subclonal architecture that occur during the course of treatment probably are not determined solely by the direct effect of cancer therapy on cancer cell vitality, but also by its impact on TME [49], and by its interference into the clonal competition or, in a broader sense, into the interclonal interactions [48].

HGSOC evolution over the course of treatment have been analyzed in several studies. Recently, paired tumor samples taken before and after first line of platinum-based chemotherapy have been compared using whole-exome sequencing (WES) and single nucleotide polymorphism profiling [50]. While only $58 \%$ of somatic mutations were conserved between matched tumor biopsies, 27 and 15\% of them were found to be relapse- and primary-unique, indicating the existence of substantial genetic heterogeneity between primary and recurrent tumors. The majority of tumor pairs demonstrated complex clonal dynamics, with some of the subclonal mutations increasing and another decreasing in frequency between primary and relapse samples. Although all but four biopsies contained subclonal mutations, its frequency was relatively low suggesting a rather oligoclonal than policlonal nature of HGSOC. It should be emphasized here that the clonality analysis of a single tumor biopsy is restricted to the biopsy taken for analysis; therefore, it does not reflect the full spectrum of tumor subclonality (sampling-bias) [51]. Moreover, currently used sequencing strategies have a limited ability [52] to detect low prevalent subclones, hence a real subclonal complexity of HGSOC may be underestimated. Therefore, further studies should use more precise sequencing strategies, such as a single cell sequencing, able to identify low prevalent subclones and, consequently, providing a full insight into the spatial subclonal composition of HGSOC and its evolution over time [53].

Branched CE in the progression of HGSOC from primary to reccurent disease has also been indicated by a case study using WES and comparative genome hybridisation to compare samples taken during debulking surgery first at initial diagnosis and second at disease relapse after treatment with platinum-based chemotherapy in combination with bevacizumab [54]. Only 42 out of 102 somatic mutations were common to all samples collected whereas 21/102, 10/102 and 7/102 were unique to biopsies obtained from primary tumor, intra-pelvic and extra-pelvic recurrence, respectively. Even lower levels of concordance between the primary and the relapsed disease have been reported recently by two other studies using targeted resequencing technology to compare mutational landscape in terms of 65 selected pharmacologically relevant genes between tumor samples taken before and after treatment with at least one line of chemotherapy $[55,56]$. As one of these studies showed, the clonal architecture of recurrent tumors was more homogeneous than their primary counterparts suggesting that during ongoing evolution the majority of the somatic mutations were eliminated from cancer cell population by selective forces imposed by cancer therapy [56].

Studies provided consistent evidence that HGSOC continues evolution during the course of treatment following highly individual patterns of CE [50,54-56]. To date, however, little is known about how the differences in the evolutionary potentials of the tumors affect the clinical outcomes. In a recent paper, 135 samples from 14 patients with advanced-stage HGSOC, who received platinumbased chemotherapy, were analyzed to evaluate the relationship between ITH and survival [27]. ITH was quantified as the degree of clonal expansion using the novel MEDICC (Minimum Event Distance for Intra-tumour Copy Number Comparisons) algorithm. As expected, the degree of clonal expansion differed considerably between patients, confirming earlier conclusions that HGSOC exhibits patientspecific ITH [7, 25, 50]. Importantly, patients with higher clonal expansion had shorter progression-free and OS compared to those with low clonal expansion, suggesting that highly heterogeneous polygenomic tumors have a greater predisposition to acquire treatment resistance, and, therefore, are characterized by poorer outcomes.

All studies that have monitored HGSOC evolution over the course of treatment consistently suggest that tumor relapse originates from drug-resistant subclone/s originally present in the primary tumor that expand under selective pressure of therapeutic intervention [27, 50, 54-56]. In contrast to some other cytotoxic drugs, such as temozolomide [57], there are no evidences that the mutagenic activity of platinum could result in the generation of resistance de novo $[12,27,50]$, implying that the role of platinumbased chemotherapy in the arising of treatment resistance in HGSOC is limited to the selection of already present resistant subclones.

The fact that in all cases adjuvant chemotherapy failed to destroy resistant subclones [27, 50, 54-56] highlights that the primary cytoreductive surgery carried out precisely is essential in the management of HGSOC. From the HGSOC heterogeneity point of view, malignant lesions should be removed to the greatest extent possible to achieve long-term clinical benefits from the applied therapy. Otherwise, minor resistant subclonal populations preoperatively widely distributed in tumor space may persist in the RD contributing to the rapid development of chemoresistance. It is clearly reflected by clinical observations indicating that the amount of RD left after primary surgery is a major 
prognostic factor for survival in patients with EOC and the probability of emergence of resistance increases and the time to resistance decreases with the volume of RD [58, 59]. Since RD should be regarded as a reservoir of resistant subclones, the current efforts to reduce its amount by allowing resection of additional malignant tissue that normally remains invisible during surgery represent a very promising way to optimize therapy [60].

\section{Conclusions and future directions}

Advances in sequencing techniques have allowed us to look into the evolutionary nature of HGSOC, which in the light of current evidences can explain the relapsing course of the disease observed in clinical practice. Since only minimal improvement in the survival of patients treated with standard therapy has been observed in the last decade, novel molecular targeted therapies are of great interest in HGSOC [61]. However, both spatial and temporal ITH pose a major challenge for personalized medicine [62], and greater knowledge of the molecular rules that drive tumor evolution through space and time is required to achieve a long-term clinical benefit from personalized therapy.

Since growing amount of evidence suggests that HGSOC relapse arises from outgrowth of pre-existing drug-resistant subclonal populations, further integrative genomic and phenotypic analyses using precise sequencing techniques should be carried out to define the molecular and genotypic signatures of resistant subclones. These data, respectively cataloged, could be used to evaluate the differences in the resistance patterns between individual patients and also could serve as a starting point for the design of novel therapeutic strategies. Further pre-clinical studies should give answer to a number of intriguing questions: (1) when do resistant subclones arise during the HGSOC evolution? (2) Whether they are distributed randomly or stochastically within the primary tumor? (3) What types of functional relationships do link them with dominant clones and surrounding non-malignant cells? (4) What is the role of microenvironmental niches in their selection or storage? (5) Whether their genotypes or phenotypes have a decisive influence on their positive selection? (6) Whether they are able to lead to recurrence autonomously or need support from the surrounding cells?

Personalized medicine requires tools to provide precise data on the subclonal composition of a patient's tumor at the time of diagnosis, and which will also allow for regular tracking of its changes in relation to the therapeutic intervention [63]. With the knowledge of how the subclonal composition of tumor changes under therapy, we will be able to set the combined or sequential treatment that can prevent selection of resistant subclones [64]. Therefore, more emphasis should be placed on the improvement of non-invasive approaches like the circulating plasma cellfree DNA sequencing whose usefulness in determining HGSOC subclonality has been recently demonstrated [65, 66].

Although existing evidences suggest that HGSOC displays highly individual patterns of CE, they are based on a relatively small number of cases. Therefore, further genomic analyses on representative groups of cases at different clinical stages should assess to what extent patterns of evolution are reproducible between patients and to what extent they are predictable in individual patients.

Heterogeneity is a hallmark of HGSOC. It must, therefore, be taken into account during efforts to improve efficiency of standard therapy, as well as during design of novel personalized therapeutic strategies.

\section{Compliance with ethical standards}

Confict of interest Author Aleksander Salomon-Perzyński declares that he has no conflict of interest. Author Magdalena SalomonPerzyńska declares that she has no conflict of interest. Author Bogdan Michalski declares that he has no conflict of interest. Author Violetta Skrzypulec-Plinta declares that she has no conflict of interest.

Funding This article was not funded by any funding body.

Open Access This article is distributed under the terms of the Creative Commons Attribution 4.0 International License (http:// creativecommons.org/licenses/by/4.0/), which permits unrestricted use, distribution, and reproduction in any medium, provided you give appropriate credit to the original author(s) and the source, provide a link to the Creative Commons license, and indicate if changes were made.

\section{References}

1. Ferlay J, Soerjomataram I, Dikshit R, Eser S, Mathers C, Rebelo M, Parkin DM, Forman D, Bray F (2015) Cancer incidence and mortality worldwide: sources, methods and major patterns in GLOBOCAN 2012. Int J Cancer 136(5):E359-E386. doi:10.1002/ijc.29210

2. Bowtell DD (2010) The genesis and evolution of high-grade serous ovarian cancer. Nat Rev Cancer 10(11):803-808. doi: $10.1038 / \mathrm{nrc} 2946$

3. Cooke SL, Brenton JD (2011) Evolution of platinum resistance in high-grade serous ovarian cancer. Lancet Oncol 12(12):11691174. doi:10.1016/s1470-2045(11)70123-1

4. de Bruin EC, McGranahan N, Mitter R, Salm M, Wedge DC, Yates L, Jamal-Hanjani M, Shafi S, Murugaesu N, Rowan AJ, Gronroos E, Muhammad MA, Horswell S, Gerlinger M, Varela I, Jones D, Marshall J, Voet T, Van Loo P, Rassl DM, Rintoul RC, Janes SM, Lee SM, Forster M, Ahmad T, Lawrence D, Falzon M, Capitanio A, Harkins TT, Lee CC, Tom W, Teefe E, Chen SC, Begum S, Rabinowitz A, Phillimore B, Spencer-Dene B, Stamp G, Szallasi Z, Matthews N, Stewart A, Campbell P, Swanton C (2014) Spatial and temporal diversity in genomic 
instability processes defines lung cancer evolution. Science 346(6206):251-256. doi:10.1126/science. 1253462

5. Gerlinger M, Horswell S, Larkin J, Rowan AJ, Salm MP, Varela I, Fisher R, McGranahan N, Matthews N, Santos CR, Martinez P, Phillimore B, Begum S, Rabinowitz A, Spencer-Dene B, Gulati S, Bates PA, Stamp G, Pickering L, Gore M, Nicol DL, Hazell S, Futreal PA, Stewart A, Swanton C (2014) Genomic architecture and evolution of clear cell renal cell carcinomas defined by multiregion sequencing. Nat Genet 46(3):225-233. doi:10.1038/ ng. 2891

6. Campbell PJ, Yachida S, Mudie LJ, Stephens PJ, Pleasance ED, Stebbings LA, Morsberger LA, Latimer C, McLaren S, Lin ML, McBride DJ, Varela I, Nik-Zainal SA, Leroy C, Jia M, Menzies A, Butler AP, Teague JW, Griffin CA, Burton J, Swerdlow H, Quail MA, Stratton MR, Iacobuzio-Donahue C, Futreal PA (2010) The patterns and dynamics of genomic instability in metastatic pancreatic cancer. Nature 467(7319):1109-1113. doi:10.1038/nature09460

7. Bashashati A, Ha G, Tone A, Ding J, Prentice LM, Roth A, Rosner J, Shumansky K, Kalloger S, Senz J, Yang W, McConechy M, Melnyk N, Anglesio M, Luk MT, Tse K, Zeng T, Moore R, Zhao Y, Marra MA, Gilks B, Yip S, Huntsman DG, McAlpine JN, Shah SP (2013) Distinct evolutionary trajectories of primary high-grade serous ovarian cancers revealed through spatial mutational profiling. J Pathol 231(1):21-34. doi:10.1002/path.4230

8. Lohr JG, Stojanov P, Carter SL, Cruz-Gordillo P, Lawrence MS, Auclair D, Sougnez C, Knoechel B, Gould J, Saksena G, Cibulskis K, McKenna A, Chapman MA, Straussman R, Levy J, Perkins LM, Keats JJ, Schumacher SE, Rosenberg M, Getz G, Golub TR (2014) Widespread genetic heterogeneity in multiple myeloma: implications for targeted therapy. Cancer Cell 25(1):91-101. doi:10.1016/j.ccr.2013.12.015

9. Sottoriva A, Spiteri I, Piccirillo SG, Touloumis A, Collins VP, Marioni JC, Curtis C, Watts C, Tavare S (2013) Intratumor heterogeneity in human glioblastoma reflects cancer evolutionary dynamics. Proc Natl Acad Sci USA 110(10):4009-4014. doi:10.1073/pnas.1219747110

10. Burrell RA, Swanton C (2014) Tumour heterogeneity and the evolution of polyclonal drug resistance. Mol Oncol 8(6):10951111. doi:10.1016/j.molonc.2014.06.005

11. Bell D, Berchuck A, Birrer M, Chien J, Cramer DW, Dao F, Dhir R, DiSaia P, Gabra H, Glenn P, Godwin AK, Gross J, Hartmann L, Huang M, Huntsman DG, Iacocca M, Imielinski M, Kalloger S, Karlan BY, Levine DA, Mills GB, Morrison C, Mutch D, Olvera N, Orsulic S, Park K, Petrelli N, Rabeno B, Rader JS, Sikic BI, Smith-McCune K, Sood AK, Bowtell D, Penny R, Testa JR, Chang K, Dinh HH, Drummond JA, Fowler G, Gunaratne P, Hawes AC, Kovar CL, Lewis LR, Morgan MB, Newsham IF, Santibanez J, Reid JG, Trevino LR, Wu YQ, Wang M, Muzny DM, Wheeler DA, Gibbs RA, Getz G, Lawrence MS, Cibulskis K, Sivachenko AY, Sougnez C, Voet D, Wilkinson J, Bloom T, Ardlie K, Fennell T, Baldwin J, Gabriel S, Lander ES, Ding LL, Fulton RS, Koboldt DC, McLellan MD, Wylie T, Walker J, O'Laughlin M, Dooling DJ, Fulton L, Abbott R, Dees ND, Zhang Q, Kandoth C, Wendl M, Schierding W, Shen D, Harris CC, Schmidt H, Kalicki J, Delehaunty KD, Fronick CC, Demeter R, Cook L, Wallis JW, Lin L, Magrini VJ, Hodges JS, Eldred JM, Smith SM, Pohl CS, Vandin F, Raphael BJ, Weinstock GM, Mardis ER, Wilson RK, Meyerson M, Winckler W, Getz G, Verhaak RG, Carter SL, Mermel CH, Saksena G, Nguyen H, Onofrio RC, Lawrence MS, Hubbard D, Gupta S, Crenshaw A, Ramos AH, Ardlie K, Chin L, Protopopov A, Zhang J, Kim TM, Perna I, Xiao Y, Zhang H, Ren G, Sathiamoorthy N, Park RW, Lee E, Park PJ, Kucherlapati R, Absher M, Waite L, Sherlock G, Brooks JD, Li JZ, Xu J, Myers RM, Laird W, Cope L, Herman JG, Shen H, Weisenberger DJ, Noushmehr H, Pan F, Triche T Jr,
Berman BP, Van Den Berg DJ, Buckley J, Baylin SB, Spellman PT, Purdom E, Neuvial P, Bengtsson H, Jakkula LR, Durinck S, Han J, Dorton S, Marr H, Choi YG, Wang V, Wang NJ, Ngai J, Conboy JG, Parvin B, Feiler HS, Speed TP, Gray JW, Levine A, Socci ND, Liang Y, Taylor BS, Schultz N, Borsu L, Lash AE, Brennan C, Viale A, Sander C, Ladanyi M, Hoadley KA, Meng S, Du Y, Shi Y, Li L, Turman YJ, Zang D, Helms EB, Balu S, Zhou X, Wu J, Topal MD, Hayes DN, Perou CM, Getz G, Voet D, Saksena G, Zhang J, Zhang H, Wu CJ, Shukla S, Cibulskis K, Lawrence MS, Sivachenko A, Jing R, Park RW, Liu Y, Park PJ, Noble M, Chin L, Carter H, Kim D, Karchin R, Spellman PT, Purdom E, Neuvial P, Bengtsson H, Durinck S, Han J, Korkola JE, Heiser LM, Cho RJ, Hu Z, Parvin B, Speed TP, Gray JW, Schultz N, Cerami E, Taylor BS, Olshen A, Reva B, Antipin Y, Shen R, Mankoo P, Sheridan R, Ciriello G, Chang WK, Bernanke JA, Borsu L, Levine DA, Ladanyi M, Sander C, Haussler D, Benz CC, Stuart JM, Benz SC, Sanborn JZ, Vaske CJ, Zhu J, Szeto C, Scott GK, Yau C, Hoadley KA, Du Y, Balu S, Hayes DN, Perou CM, Wilkerson MD, Zhang N, Akbani R, Baggerly KA, Yung WK, Mills GB, Weinstein JN, Penny R, Shelton T, Grimm D, Hatfield M, Morris S, Yena P, Rhodes P, Sherman M, Paulauskis J, Millis S, Kahn A, Greene JM, Sfeir R, Jensen MA, Chen J, Whitmore J, Alonso S, Jordan J, Chu A, Zhang J, Barker A, Compton C, Eley G, Ferguson M, Fielding P, Gerhard DS, Myles R, Schaefer C, Mills Shaw KR, Vaught J, Vockley JB, Good PJ, Guyer MS, Ozenberger B, Peterson J, Thomson E (2011) Integrated genomic analyses of ovarian carcinoma. Nature 474(7353):609-615. doi:10.1038/nature10166

12. Patch AM, Christie EL, Etemadmoghadam D, Garsed DW, George J, Fereday S, Nones K, Cowin P, Alsop K, Bailey PJ, Kassahn KS, Newell F, Quinn MC, Kazakoff S, Quek K, Wilhelm-Benartzi C, Curry E, Leong HS, Hamilton A, Mileshkin L, Au-Yeung G, Kennedy C, Hung J, Chiew YE, Harnett P, Friedlander M, Quinn M, Pyman J, Cordner S, O'Brien P, Leditschke J, Young G, Strachan K, Waring P, Azar W, Mitchell C, Traficante N, Hendley J, Thorne H, Shackleton M, Miller DK, Arnau GM, Tothill RW, Holloway TP, Semple T, Harliwong I, Nourse C, Nourbakhsh E, Manning S, Idrisoglu S, Bruxner TJ, Christ AN, Poudel B, Holmes O, Anderson M, Leonard C, Lonie A, Hall N, Wood S, Taylor DF, Xu Q, Fink JL, Waddell N, Drapkin R, Stronach E, Gabra H, Brown R, Jewell A, Nagaraj SH, Markham E, Wilson PJ, Ellul J, McNally O, Doyle MA, Vedururu R, Stewart C, Lengyel E, Pearson JV, Waddell N, deFazio A, Grimmond SM, Bowtell DD (2015) Whole-genome characterization of chemoresistant ovarian cancer. Nature 521(7553):489-494. doi:10.1038/ nature 14410

13. Hanahan D, Weinberg RA (2011) Hallmarks of cancer: the next generation. Cell 144(5):646-674. doi:10.1016/j.cell.2011.02.013

14. Lee AJ, Endesfelder D, Rowan AJ, Walther A, Birkbak NJ, Futreal PA, Downward J, Szallasi Z, Tomlinson IP, Howell M, Kschischo M, Swanton C (2011) Chromosomal instability confers intrinsic multidrug resistance. Cancer Res 71(5):1858-1870. doi:10.1158/0008-5472.can-10-3604

15. Bakhoum SF, Danilova OV, Kaur P, Levy NB, Compton DA (2011) Chromosomal instability substantiates poor prognosis in patients with diffuse large B-cell lymphoma. Clin Cancer Res 17(24):7704-7711. doi:10.1158/1078-0432.ccr-11-2049

16. Morris LG, Riaz N, Desrichard A, Senbabaoglu Y, Hakimi AA, Makarov V, Reis-Filho JS, Chan TA (2016) Pan-cancer analysis of intratumor heterogeneity as a prognostic determinant of survival. Oncotarget 7(9):10051-10063. doi:10.18632/ oncotarget.7067

17. Turner NC, Reis-Filho JS (2012) Genetic heterogeneity and cancer drug resistance. Lancet Oncol 13(4):e178-e185. doi:10.1016/ s1470-2045(11)70335-7 
18. Birkbak NJ, Eklund AC, Li Q, McClelland SE, Endesfelder D, Tan P, Tan IB, Richardson AL, Szallasi Z, Swanton C (2011) Paradoxical relationship between chromosomal instability and survival outcome in cancer. Cancer Res 71(10):3447-3452. doi:10.1158/0008-5472.can-10-3667

19. Baumbusch LO, Helland A, Wang Y, Liestol K, Schaner ME, Holm R, Etemadmoghadam D, Alsop K, Brown P, Mitchell G, Fereday S, DeFazio A, Bowtell DD, Kristensen GB, Lingjaerde OC, Borresen-Dale AL (2013) High levels of genomic aberrations in serous ovarian cancers are associated with better survival. PLoS One 8(1):e54356. doi:10.1371/journal. pone.0054356

20. Pennington KP, Walsh T, Harrell MI, Lee MK, Pennil CC, Rendi MH, Thornton A, Norquist BM, Casadei S, Nord AS, Agnew KJ, Pritchard CC, Scroggins S, Garcia RL, King MC, Swisher EM (2014) Germline and somatic mutations in homologous recombination genes predict platinum response and survival in ovarian, fallopian tube, and peritoneal carcinomas. Clin Cancer Res 20(3):764-775. doi:10.1158/1078-0432. ccr-13-2287

21. Norquist B, Wurz KA, Pennil CC, Garcia R, Gross J, Sakai W, Karlan BY, Taniguchi T, Swisher EM (2011) Secondary somatic mutations restoring BRCA $1 / 2$ predict chemotherapy resistance in hereditary ovarian carcinomas. J Clin Oncol 29(22):3008-3015. doi:10.1200/jco.2010.34.2980

22. Leary A, Genestie C, Adam J, Le Formal A, Pautier P, Lhomme C, Auguste A (2015) Genomic profile and immune infiltrate in paired ovarian cancer (OC) samples pre-and postneoadjuvant chemotherapy (NC). In: ASCO Annual Meeting Proceedings, vol 15(suppl), p 5575

23. McGranahan N, Favero F, de Bruin EC, Birkbak NJ, Szallasi Z, Swanton C (2015) Clonal status of actionable driver events and the timing of mutational processes in cancer evolution. Sci Transl Med 7(283):283ra254. doi:10.1126/scitranslmed. aaa1408

24. Greaves M, Maley CC (2012) Clonal evolution in cancer. Nature 481(7381):306-313. doi:10.1038/nature 10762

25. Hoogstraat M, de Pagter MS, Cirkel GA, van Roosmalen MJ, Harkins TT, Duran K, Kreeftmeijer J, Renkens I, Witteveen PO, Lee CC, Nijman IJ, Guy T, van 't Slot R, Jonges TN, Lolkema MP, Koudijs MJ, Zweemer RP, Voest EE, Cuppen E, Kloosterman WP (2014) Genomic and transcriptomic plasticity in treatment-naive ovarian cancer. Genome Res 24(2):200-211. doi:10.1101/gr.161026.113

26. Lee JY, Yoon JK, Kim B, Kim S, Kim MA, Lim H, Bang D, Song YS (2015) Tumor evolution and intratumor heterogeneity of an epithelial ovarian cancer investigated using nextgeneration sequencing. BMC Cancer 15:85. doi:10.1186/ s12885-015-1077-4

27. Schwarz RF, Ng CK, Cooke SL, Newman S, Temple J, Piskorz AM, Gale D, Sayal K, Murtaza M, Baldwin PJ, Rosenfeld N, Earl HM, Sala E, Jimenez-Linan M, Parkinson CA, Markowetz F, Brenton JD (2015) Spatial and temporal heterogeneity in highgrade serous ovarian cancer: a phylogenetic analysis. PLoS Med 12(2):e1001789. doi:10.1371/journal.pmed.1001789

28. Junttila MR, de Sauvage FJ (2013) Influence of tumour microenvironment heterogeneity on therapeutic response. Nature 501(7467):346-354. doi:10.1038/nature12626

29. Mumenthaler SM, Foo J, Choi NC, Heise N, Leder K, Agus DB, Pao W, Michor F, Mallick P (2015) The impact of microenvironmental heterogeneity on the evolution of drug resistance in cancer cells. Cancer Inform 14(Suppl 4):19-31. doi:10.4137/cin. s19338

30. Heindl A, Nawaz S, Yuan Y (2015) Mapping spatial heterogeneity in the tumor microenvironment: a new era for digital pathology. Lab Invest 95(4):377-384. doi:10.1038/labinvest.2014.155
31. Aparicio S, Caldas C (2013) The implications of clonal genome evolution for cancer medicine. $\mathrm{N}$ Engl $\mathrm{J}$ Med 368(9):842-851. doi:10.1056/NEJMra1204892

32. Marusyk A, Tabassum DP, Altrock PM, Almendro V, Michor F, Polyak K (2014) Non-cell-autonomous driving of tumour growth supports sub-clonal heterogeneity. Nature 514(7520):54-58. doi:10.1038/nature13556

33. Cassidy JW, Caldas C, Bruna A (2015) Maintaining tumor heterogeneity in patient-derived tumor xenografts. Cancer Res 75(15):2963-2968. doi:10.1158/0008-5472.can-15-0727

34. Caiado F, Silva-Santos B, Norell H (2016) Intra-tumour heterogeneity—going beyond genetics. FEBS J 283(12):22452258. doi:10.1111/febs.13705

35. Tape CJ, Ling S, Dimitriadi M, McMahon KM, Worboys JD, Leong HS, Norrie IC, Miller CJ, Poulogiannis G, Lauffenburger DA, Jorgensen C (2016) Oncogenic KRAS regulates tumor cell signaling via stromal reciprocation. Cell 165(4):910-920. doi:10.1016/j.cell.2016.03.029

36. Fotopoulou C, Cunnea P, Rama NR, Wulandari R, Gorgy T, Gabra H, Stronach EA (2015) Characterising phenotypically relevant intratumoural heterogeneity in high grade serous ovarian cancer. In: ASCO Annual Meeting Proceedings, vol 15_ suppl, p e16569

37. Hamilton CA, Miller A, Miller C, Krivak TC, Farley JH, Chernofsky MR, Stany MP, Rose GS, Markman M, Ozols RF, Armstrong DK, Maxwell GL (2011) The impact of disease distribution on survival in patients with stage III epithelial ovarian cancer cytoreduced to microscopic residual: a Gynecologic Oncology Group study. Gynecol Oncol 122(3):521-526. doi:10.1016/j.ygyno.2011.04.041

38. Inda MM, Bonavia R, Mukasa A, Narita Y, Sah DW, Vandenberg S, Brennan C, Johns TG, Bachoo R, Hadwiger P, Tan P, Depinho RA, Cavenee W, Furnari F (2010) Tumor heterogeneity is an active process maintained by a mutant EGFR-induced cytokine circuit in glioblastoma. Genes Dev 24(16):17311745. doi:10.1101/gad.1890510

39. Cleary AS, Leonard TL, Gestl SA, Gunther EJ (2014) Tumour cell heterogeneity maintained by cooperating subclones in Wnt-driven mammary cancers. Nature 508(7494):113-117. doi:10.1038/nature 13187

40. Chesi M, Robbiani DF, Sebag M, Chng WJ, Affer M, Tiedemann R, Valdez R, Palmer SE, Haas SS, Stewart AK, Fonseca R, Kremer R, Cattoretti G, Bergsagel PL (2008) AID-dependent activation of a MYC transgene induces multiple myeloma in a conditional mouse model of post-germinal center malignancies. Cancer Cell 13(2):167-180. doi:10.1016/j. ccr.2008.01.007

41. Lee JM, Mhawech-Fauceglia P, Lee N, Parsanian LC, Lin YG, Gayther SA, Lawrenson K (2013) A three-dimensional microenvironment alters protein expression and chemosensitivity of epithelial ovarian cancer cells in vitro. Lab Invest 93(5):528-542. doi:10.1038/labinvest.2013.41

42. Zietarska M, Maugard CM, Filali-Mouhim A, Alam-Fahmy M, Tonin PN, Provencher DM, Mes-Masson AM (2007) Molecular description of a 3D in vitro model for the study of epithelial ovarian cancer (EOC). Mol Carcinog 46(10):872-885. doi:10.1002/mc.20315

43. Yang Z, Zhao X (2011) A 3D model of ovarian cancer cell lines on peptide nanofiber scaffold to explore the cell-scaffold interaction and chemotherapeutic resistance of anticancer drugs. Int $\mathbf{J}$ Nanomed 6:303-310. doi:10.2147/ijn.s15279

44. Chien J, Kuang R, Landen C, Shridhar V (2013) Platinum-sensitive recurrence in ovarian cancer: the role of tumor microenvironment. Front Oncol 3:251. doi:10.3389/fonc.2013.00251

45. Narod S (2016) Can advanced-stage ovarian cancer be cured? Nat Rev Clin Oncol 13(4):255-261. doi:10.1038/nrclinonc.2015.224 
46. Melchardt T, Hufnagl C, Weinstock DM, Kopp N, Neureiter D, Trankenschuh W, Hackl H, Weiss L, Rinnerthaler G, Hartmann TN, Greil R, Weigert O, Egle A (2016) Clonal evolution in relapsed and refractory diffuse large B-cell lymphoma is characterized by high dynamics of subclones. Oncotarget. doi:10.18632/oncotarget.9860

47. Ding L, Ley TJ, Larson DE, Miller CA, Koboldt DC, Welch JS, Ritchey JK, Young MA, Lamprecht T, McLellan MD, McMichael JF, Wallis JW, Lu C, Shen D, Harris CC, Dooling DJ, Fulton RS, Fulton LL, Chen K, Schmidt H, Kalicki-Veizer J, Magrini VJ, Cook L, McGrath SD, Vickery TL, Wendl MC, Heath S, Watson MA, Link DC, Tomasson MH, Shannon WD, Payton JE, Kulkarni S, Westervelt P, Walter MJ, Graubert TA, Mardis ER, Wilson RK, DiPersio JF (2012) Clonal evolution in relapsed acute myeloid leukaemia revealed by wholegenome sequencing. Nature 481(7382):506-510. doi:10.1038/ nature 10738

48. Landau DA, Carter SL, Stojanov P, McKenna A, Stevenson K, Lawrence MS, Sougnez C, Stewart C, Sivachenko A, Wang L, Wan Y, Zhang W, Shukla SA, Vartanov A, Fernandes SM, Saksena G, Cibulskis K, Tesar B, Gabriel S, Hacohen N, Meyerson M, Lander ES, Neuberg D, Brown JR, Getz G, Wu CJ (2013) Evolution and impact of subclonal mutations in chronic lymphocytic leukemia. Cell 152(4):714-726. doi:10.1016/j. cell.2013.01.019

49. Skolekova S, Matuskova M, Bohac M, Toro L, Durinikova E, Tyciakova S, Demkova L, Gursky J, Kucerova L (2016) Cisplatin-induced mesenchymal stromal cells-mediated mechanism contributing to decreased antitumor effect in breast cancer cells. Cell Commun Signal CCS 14:4. doi:10.1186/s12964-016-0127-0

50. Lambrechts S, Smeets D, Moisse M, Braicu EI, Vanderstichele A, Zhao H, Van Nieuwenhuysen E, Berns E, Sehouli J, Zeillinger R, Darb-Esfahani S, Cacsire Castillo-Tong D, Lambrechts D, Vergote I (2016) Genetic heterogeneity after first-line chemotherapy in high-grade serous ovarian cancer. Eur J Cancer 53:51-64. doi:10.1016/j.ejca.2015.11.001

51. Gerlinger M, Rowan AJ, Horswell S, Larkin J, Endesfelder D, Gronroos E, Martinez P, Matthews N, Stewart A, Tarpey P, Varela I, Phillimore B, Begum S, McDonald NQ, Butler A, Jones D, Raine K, Latimer C, Santos CR, Nohadani M, Eklund AC, Spencer-Dene B, Clark G, Pickering L, Stamp G, Gore M, Szallasi Z, Downward J, Futreal PA, Swanton C (2012) Intratumor heterogeneity and branched evolution revealed by multiregion sequencing. N Engl J Med 366(10):883-892. doi:10.1056/ NEJMoa1113205

52. Griffith M, Miller CA, Griffith OL, Krysiak K, Skidmore ZL, Ramu A, Walker JR, Dang HX, Trani L, Larson DE, Demeter RT, Wendl MC, McMichael JF, Austin RE, Magrini V, McGrath SD, Ly A, Kulkarni S, Cordes MG, Fronick CC, Fulton RS, Maher CA, Ding L, Klco JM, Mardis ER, Ley TJ, Wilson RK (2015) Optimizing cancer genome sequencing and analysis. Cell Syst 1(3):210-223. doi:10.1016/j.cels.2015.08.015

53. Zhang X, Marjani SL, Hu Z, Weissman SM, Pan X, Wu S (2016) Single-cell sequencing for precise cancer research: progress and prospects. Cancer Res 76(6):1305-1312. doi:10.1158/00085472.can-15-1907

54. Mota A, Trivino JC, Rojo-Sebastian A, Martinez-Ramirez A, Chiva L, Gonzalez-Martin A, Garcia JF, Garcia-Sanz P, MorenoBueno G (2015) Intra-tumor heterogeneity in TP53 null High Grade Serous Ovarian Carcinoma progression. BMC Cancer 15:940. doi:10.1186/s12885-015-1952-Z

55. Paracchini L, Mannarino L, Craparotta I, Romualdi C, Fruscio R, Grassi T, Fotia V, Caratti G, Perego P, Calura E, Clivio L, D'Incalci M, Beltrame L, Marchini S (2016) Regional and temporal heterogeneity of epithelial ovarian cancer tumor biopsies: implications for therapeutic strategies. Oncotarget. doi:10.18632/ oncotarget.10505

56. Beltrame L, Di Marino M, Fruscio R, Calura E, Chapman B, Clivio L, Sina F, Mele C, Iatropoulos P, Grassi T, Fotia V, Romualdi C, Martini P, Noris M, Paracchini L, Craparotta I, Petrillo M, Milani R, Perego P, Ravaggi A, Zambelli A, Ronchetti E, D'Incalci M, Marchini S (2015) Profiling cancer gene mutations in longitudinal epithelial ovarian cancer biopsies by targeted next-generation sequencing: a retrospective study. Ann Oncol 26(7):1363-1371. doi:10.1093/annonc/mdv164

57. Johnson BE, Mazor T, Hong C, Barnes M, Aihara K, McLean CY, Fouse SD, Yamamoto S, Ueda H, Tatsuno K, Asthana S, Jalbert LE, Nelson SJ, Bollen AW, Gustafson WC, Charron E, Weiss WA, Smirnov IV, Song JS, Olshen AB, Cha S, Zhao Y, Moore RA, Mungall AJ, Jones SJ, Hirst M, Marra MA, Saito N, Aburatani H, Mukasa A, Berger MS, Chang SM, Taylor BS, Costello JF (2014) Mutational analysis reveals the origin and therapy-driven evolution of recurrent glioma. Science 343(6167):189-193. doi:10.1126/science.1239947

58. Horowitz NS, Miller A, Rungruang B, Richard SD, Rodriguez N, Bookman MA, Hamilton CA, Krivak TC, Maxwell GL (2015) Does aggressive surgery improve outcomes? Interaction between preoperative disease burden and complex surgery in patients with advanced-stage ovarian cancer: an analysis of GOG 182. J Clin Oncol 33(8):937-943. doi:10.1200/jco.2014.56.3106

59. Winter WE 3rd, Maxwell GL, Tian C, Carlson JW, Ozols RF, Rose PG, Markman M, Armstrong DK, Muggia F, McGuire WP (2007) Prognostic factors for stage III epithelial ovarian cancer: a Gynecologic Oncology Group Study. J Clin Oncol 25(24):36213627. doi:10.1200/jco.2006.10.2517

60. Hoogstins CE, Tummers QR, Gaarenstroom KN, de Kroon CD, Trimbos JB, Bosse T, Smit VT, Vuyk J, van de Velde CJ, Cohen AF, Low PS, Burggraaf J, Vahrmeijer AL (2016) A Novel tumor-specific agent for intraoperative near-infrared fluorescence imaging: a translational study in healthy volunteers and patients with ovarian cancer. Clin Cancer Res 22(12):2929-2938. doi:10.1158/1078-0432.ccr-15-2640

61. Petrillo M, Nero C, Amadio G, Gallo D, Fagotti A, Scambia G (2016) Targeting the hallmarks of ovarian cancer: the big picture. Gynecol Oncol 142(1):176-183. doi:10.1016/j. ygyno.2016.03.037

62. Blair BG, Bardelli A, Park BH (2014) Somatic alterations as the basis for resistance to targeted therapies. J Pathol 232(2):244254. doi:10.1002/path. 4278

63. Frenel JS, Carreira S, Goodall J, Roda D, Perez-Lopez R, Tunariu N, Riisnaes R, Miranda S, Figueiredo I, Nava-Rodrigues D, Smith A, Leux C, Garcia-Murillas I, Ferraldeschi R, Lorente D, Mateo J, Ong M, Yap TA, Banerji U, Gasi Tandefelt D, Turner N, Attard G, de Bono JS (2015) Serial next-generation sequencing of circulating cell-free DNA evaluating tumor clone response to molecularly targeted drug administration. Clin Cancer Res 21(20):4586-4596. doi:10.1158/1078-0432.ccr-15-0584

64. Hiley C, de Bruin EC, McGranahan N, Swanton C (2014) Deciphering intratumor heterogeneity and temporal acquisition of driver events to refine precision medicine. Genome Biol 15(8):453. doi:10.1186/s13059-014-0453-8

65. Arend RC, Londono AI, Alvarez RD, Huh WK, Bevis KS, Leath CA (2016) Straughn JM Circulating cell-free DNA: The future of personalized medicine in ovarian cancer management. In: ASCO Annual Meeting Proceedings, vol 15 suppl, p 5577

66. Londono AI, Yeh C-H, Alvarez RD, Leath CA, Straughn JM, Arend RC (2016) Correlation of mutation status between tissue and blood-drop liquid biopsies from ovarian cancer patients following chemotherapy. In: ASCO Annual Meeting Proceedings, vol 15_suppl, p e13108 